\title{
PENGEMBANGAN PERANGKAT PEMBELAJARAN KIMIA ANALISIS BERBASISMODEL PEMBELAJARAN GUIDED DISCOVERY UNTUK MELATIH PEMAHAMAN KONSEP DAN KETERAMPILAN BERPIKIR KRITIS SISWA SMK
}

\author{
${ }^{(1)}$ Wahyuni \\ ${ }^{(2)}$ Tukiran \\ ${ }^{(3)}$ Widodo. \\ ${ }^{(1)}$ Mahasiswa Pendidikan Sains Pascasarjana Unesa \\ ${ }^{(2)}$ Dosen Pasca SarjanaUniversitas Negeri Surabaya \\ ${ }^{(3)}$ Dosen Pasca SarjanaUniversitas Negeri Surabaya
}

\begin{abstract}
Abstrak: Penelitian ini bertujuan untuk mengembangkan perangkat pembelajaran Kimia Analisis siswa SMK kelas XI pada pokok bahasan Melakukan Analisis Air dan Mineral (MAAM) melalui model pembelajaran guided discovery. Desain pengembangan pada penelitian ini menggunakan model Dick and Carey, sedangkan rancangan uji coba menggunakan One Group Pretest-Posttest Design. Temuan penelitian ini yaitu perangkat pembelajaran yang dikembangkan secara umum berkategori baik. Hasil analisis keterbacaan BAS dan LKS mudah dipahami dan terbaca oleh siswa. Keterlaksanaan RPP berkategori baik sedangkan aktivitas siswa yang dominan adalah melakukan pengamatan, berdiskusi, dan berpendapat masing-masing adalah 19\%, 16\%, dan 13\%. Berdasarkan tinjauan Kriteria Ketuntasan Minimal (KKM), model pembelajaran guided discovery juga memberikan pengaruh pada hasil belajar siswa yang berada pada kategori tuntas. Hasil penelitian ini juga menunjukkan bahwa N-gain rata-rata pemahaman konsep dan keterampilan berpikir kritis berada pada kategori tinggi. Respon siswa terhadap pembelajaran dengan model guided discovery dinilai baik. Berdasarkan hasil tersebut, disimpulkan bahwa pembelajaran pada pokok bahasan Melakukan Analisis Air dan Mineral (MAAM) melalui model guided discovery dapat melatihkan pemahaman konsep dan keterampilan berpikir kritis siswa SMK.
\end{abstract}

Kata Kunci: Model Pembelajaran Guided Discovery, Pemahaman Konsep, Keterampilan Berpikir Kritis.

\begin{abstract}
This research is purposed to develop learning instrument of chemical analysis for eleventh grade of vocational high school student on the material of conducting water analysis and mineral through guided discovery learning model. This research is designed using Dick and Carey model whereas the experimental design using One Group Pretest-Posttest Design. This finding research is learning instrument materials which developed generally becomes acceptable or good. The analysis result of hand book and work book literacy are understandable and literate for student. The implementation of lesson plan is good but students activity for observing, discussing, and delivering opinion are dominant with 19\%, 16\%, and 13\% respectively. Based on minimum completeness, guided discovery learning model also gave influence for students learning result which is on complete category. This research also described that $\mathrm{N}$-gain comprehensions of concept average and critical thinking ability are on high category level. Students response to guided discovery learning model is good. Base on this research, it completely concluded that learning on the material of conducting water analysis and mineral using guided discovery model is able to encourage students concept comprehension and critical thinking ability.
\end{abstract}

Keywords: Learning Model of Guided Discovery, Comprehension of Concept, Critical Thinking Ability

\section{PENDAHULUAN}

Berdasarkan pengamatan yang dilakukan terhadap siswa di SMK Negeri 1 Cerme Gresik diperoleh informasi bahwa penguasaan konsep kimia dan keterampilan berpikir kritis siswa masih kurang di dalam mempelajari materi kompetensi keahlian kimia analisis sedangkan penerapan model pembelajaran guided discovery kurang diterapkan dalam proses pembelajaran. Terbukti dari hasil analisa tes penguasaan konsep menunjukkan bahwa $18,19 \%$ siswa yang bisa menyelesaikan soal-soal pemahaman konsep dimana siswa mengalami kesulitan pada soal yang mengharuskan mereka untuk menafsirkan hasil reaksi kimia serta mengalami kesulitan dalam mengklasifikasikan hasil suatu reaksi kimia. Sementara itu, hasil analisa angket menunjukkan bahwa siswa merasa kurang memahami konsep kimia. Hal ini ditunjukkan dengan jumlah responden yang menyatakan tidak memahami konsep kimia berjumlah $61 \%$. Salah satu pernyataan konsep kimia yang kurang dipahami siswa adalah mereka kurang mampu membaca titik akhir titrasi yang digambarkan dalam bentuk grafik. Hampir seluruh siswa tidak pernah menggambarkan titik akhir titrasi yang mereka peroleh dari titrasi kedalam bentuk grafik dan mereka kurang mampu menghubungkan suatu fenomena 
kimia disekitar mereka dengan konsep-konsep kimia yang su- dah mereka peroleh sebelumnya. Mereka cenderung mengaitkan hasil eksperimen dengan keberhasilan atau kegagalan eksperimen yang mereka lakukan tanpa mencari penyebabnya. Hal ini karena siswa kurang mampu dalam mengaplikasikan materi yang dipelajari kedalam konsep-konsep kimia yang mendukung.

Hasil analisa tes soal berpikir kritis menunjukkan $26,5 \%$ siswa dapat menyelesaikan soal-soal berpikir kritis dengan baik. Hal ini dikarenakan siswa masih kurang mampu memastikan masalah pada suatu soal untuk diselesaikan sehingga keyakinan dalam menyelesaikan soal-soal masih kurang. Sementara, hasil analisa angket keterampilan berpikir kritis menunjukkan bahwa siswa kurang mampu membedakan bagian-bagian dari analisa yang mereka lakukan misalnya saat melakukan analisa $\mathrm{Ca} 2+$ dan analisa $\mathrm{Mg} 2+$ serta siswa kurang mampu menentukan prosedur yang relevan dengan analisa yang sedang dilakukan sehingga efektivitas analisa yang dilakukan belum sesuai dengan penemuan yang terdahulu. Hal ini karena siswa mengalami kesulitan dalam mengembangkan daya pikirnya untuk berpikir secara deduktif. Berpikir secara deduktif sangat diperlukan oleh siswa SMK karena mereka harus inovatif dalam dunia kerja yang akan mereka hadapai setelah lulus atau saat mereka bekerja.

Pada analisa angket tentang model pembelajaran guided discovery menunjukkan siswa kurang terbiasa dalam merumuskan masalah dari eksperimen yang akan dilakukan dan siswa kurang terbiasa mengajukan hipotesis sebelum melakukan eksperimen. Siswa dalam melakukan eksperimen terbiasa dengan rutinitas, yaitu setelah memperoleh prosedur kerja dari guru lalu siswa melakukan eksperimen sesuai prosedur tersebut tanpa melatihkan ke siswa cara merumuskan masalah dan membuat hipotesis dari eksperimen yang sedang dilakukan serta siswa ku- rang terbiasa menghubungkan hasil eksperimen yang telah dilakukan dengan konsep-konsep kimia yang men- dukung eksperimen tersebut.

Dari hasil analisa soal yang diperoleh peneliti dapat diketahui bahwa siswa kurang mampu dalam me- nyelesaikan soal-soal pemahaman konsep dan keterampi- lan berpikir kritis. Hasil analisa soal menujukkan seluruh siswa mempunyai nilai dibawah 50 . Hal ini disebabkan siswa terbiasa setelah melakukan eksperimen tidak pernah menghubungkan analisa data yang dibuat dengan konsep kimia yang sudah mereka peroleh dan tidak ada tantangan yang dibuat guru untuk melakukan inovasi pada pengembangan hasil eksperimen yang dilakukan. Hasil wawancara terhadap guru diperoleh gambaran bahwa penanaman konsep kimia kurang karena guru lebih mengutamakan kompetensi keahlian sebagai bekal siswa bekerja supaya mereka terampil dibidang yang mereka tekuni. Sementara keterampilan berpikir kritis siswa tidak berkembang dengan baik karena guru kurang membiasakan dan melatihkan kepada siswa untuk memecahkan soal-soal yang memiliki tingkat kesukaran tinggi dengan alasan siswa akan mencapai nilai dibawah kreteria ketuntasan minimum. Disisi lain, sebagai tenaga kerja yang kompeten dibidang keahlian kimia analisis siswa harus kreatif, inovatif dan berpikir secara induktif maupun deduktif untuk menciptakan hal-hal baru guna meningkatkan nilai perindustrian dan perekonomian In- donesia menjadi lebih baik dari negara-negara maju lainnya.

Dari riset yang dilakukan oleh TIMSS (Nur, 2012) menunjukkan siswa Indonesia berada pada rangking amat rendah dalam kemampuan berpikir kritis. Hal ini ditunjukkan dari indikator berpikir kritis yang kurang mampu dikuasai oleh siswa, yaitu meliputi (1) memahami informasi komplek yang diterima, (2) teori, ana- lisis, dan pemecahan masalah, (3) pemakaian alat, prosedur, dan pemecahan masalah, dan (4) melakukan investigasi.

Pada umumnya siswa memperhatikan ketika guru menjelaskan materi pelajaran dan mau mengerjakan latihan soal-soal. Namun komunikasi siswa di kelas umumnya terjadi satu atau dua arah (antara guru dan siswa), lebih didominasi oleh guru, jarang ada siswa yang bertanya baik terhadap guru maupun temannya. Jika diberi soal latihan yang sulit, hanya sebagian kecil siswa yang men- coba menyelesaikannya, siswa lainnya hanya menunggu guru untuk membahas soal tersebut. Pembelajaran terke- san sepenuhnya tergantung pada guru, aktivitas belajar siswa rendah, siswa kurang dibimbing untuk menemukan sendiri suatu konsep kimia, sehingga tidak memacu siswa untuk berpartisipasi aktif dalam kegiatan pembelajaran. Perlu dilakukan pengkajian lanjutan tentang alternatif pembelajaran yang dapat membuat siswa memahami konsep kimia serta keterampilan berpikir kritis yang lebih baik. Upaya yang dilakukan untuk meningkatkan pemahaman konsep kimia diantaranya melakukan serangkaian riset pengembangan dan menghasilkan berbagai model serta pendekatan pembelajaran kimia. Siswa dapat mempelajari konsep-konsep dengan baik ketika siswa terlibat dalam proses induksi seperti mengamati beberapa contoh, mencari dan menguji suatu kasus dan mampu menjelaskan temuan dengan kata-kata yang tepat (Yang, 2012: 743). Pemahaman konsep merupakan alat kognitif yang dapat menyimpan kecerdasan lebih lama kemudian digunakan untuk mendesain suatu masalah (Joolingen, 1999: 385)

Salah satu model pembelajaran yang digunakan dalam mata pelajaran kimia adalah pembelajaran model guided discovery. Dalam model ini siswa dapat 
meningkatkan kemampuan dalam pengenalan pola pembelajaran, yang diperoleh melalui pemikiran intuitif dan metaforis. Pemikiran intuitif dan metaforis berguna untuk proses penemuan karena pemikiran ini memungkinkan untuk memecahkan masalah komplek (Domaingue, 1992: 13). Dengan menggunakan model pembelajaran discovery siswa dapat mengumpulkan informasi, mengklasifikasi- kan informasi, menyimpulkan informasi yang telah diterima serta menyatakan hipotesis (Swaak, 2004: 226). Siswa menunjukkan keaktifan dan keterampilan dalam proses penyelidikan karena siswa lebih efektif mem- bangun pengetahuan mereka sendiri (Balin, 2009: 2). Melalui guided discovery membuat siswa dapat melakukan pemecahan masalah, belajar mandiri, berpikir kritis, kreatif dan bukan menghafal (Akinbobola, 2009: 234). Hal ini mengiyaratkan perlunya data empiris untuk memperoleh gambaran penggunaan model guided dis- covery dalam upaya meningkatkan keterampilan berpikir lainnya seperti keterampilan berpikir kritis.

Hasil observasi yang dilakukan peneliti diperoleh infor- masi bahwa RPP yang dibuat guru selama ini tidak mencerminkan penguasaan konsep maupun berpikir kritis. Dalam membuat RPP mereka mengacu pada contoh-contoh yang sudah ada seperti RPP milik teman sejawat yang disusun tanpa melihat tujuan pembelajaran yang ingin dicapai atau guru memperoleh RPP sekedar dari internet tanpa melihat kesesuaian materi dengan strategi/model pembelajaran yang digunakan.

Di sisi lain, observasi di lapangan diperoleh sejumlah informasi bahwa buku ajar siswa dan LKS yang digunakan guru belum menunjukkan pemahaman konsep dan keterampilan berpikir kritis karena selama melakukan pengajaran kompetensi keahlian guru tidak mengunakan buku ajar siswa dan LKS yang baku. Buku yang digunakan guru untuk mengajar diambil dari saat mereka menempuh studi terdahulu atau dari hasil mereka mengikuti pelatihan dibidang kompetensi keahlian kimia analisis sehingga penyampai materi terkadang terlalu luas tidak sesuai dengan kurikulum atau tingkatan anak SMK. Di kompetensi keahlian kimia analisis guru tidak mempunyai LKS yang digunakan untuk mengajar, guru mengambil prosedur kerja dari buku-buku yang sudah ada, lalu membagikan prosedur kerja tersebut kepada siswa sebagai petunjuk kerja saat melakukan eksperimen.

Dalam upaya mengatasi permasalahan mempelajari konsep kimia diperlukan suatu data empiris tentang pengembangan perangkat pembelajaran yang lebih mengaktifkan siswa dalam proses belajarnya dan diharapkan dapat meningkatkan keterampilan berpikir kritis siswa. Salah satu perangkat pembelajaran yang perlu diteliti dalam pembelajaran kompetensi keahlian kimia analisis adalah model pembelajaran guided discovery, sehingga diperlukan bukti data empiris tentang bagaimana gambaran pengembangan perangkat model ini dalam meningkatkan pemahaman konsep kimia dan keterampilan berpikir kritis siswa.

\section{METODE}

Penelitian ini termasuk penelitian pengembangan, yang dilaksanakan untuk menghasilkan perangkat pembelajaran Kimia di SMK pada Kompetensi Keahlian Kimia Analisis menggunakan model pembelajaran guided discovery. Perangkat pembelajaran yang dikembangkan meliputi Silabus, Rencana Pelaksanaan Pembelajaran (RPP), Buku Ajar Siswa (BAS), Lembar Kegiatan Siswa (LKS), dan Lembar Penilaian (LP).

Penelitian ini terdiri dari tiga tahap, yaitu (1) pengembangan perangkat pembelajaran, (2) validasi perangkat pembelajaran, dan (3) implementasi perangkat pembelajaran.Rancangan perangkat pembelajaran dilakukan menggunakan model Dick dan Carey (2003:2). Secara rinci urutan perencangan dan pengembangan perangkat pembelajaran tersebut seperti ditunjukkan pada diagram alir berikut ini:

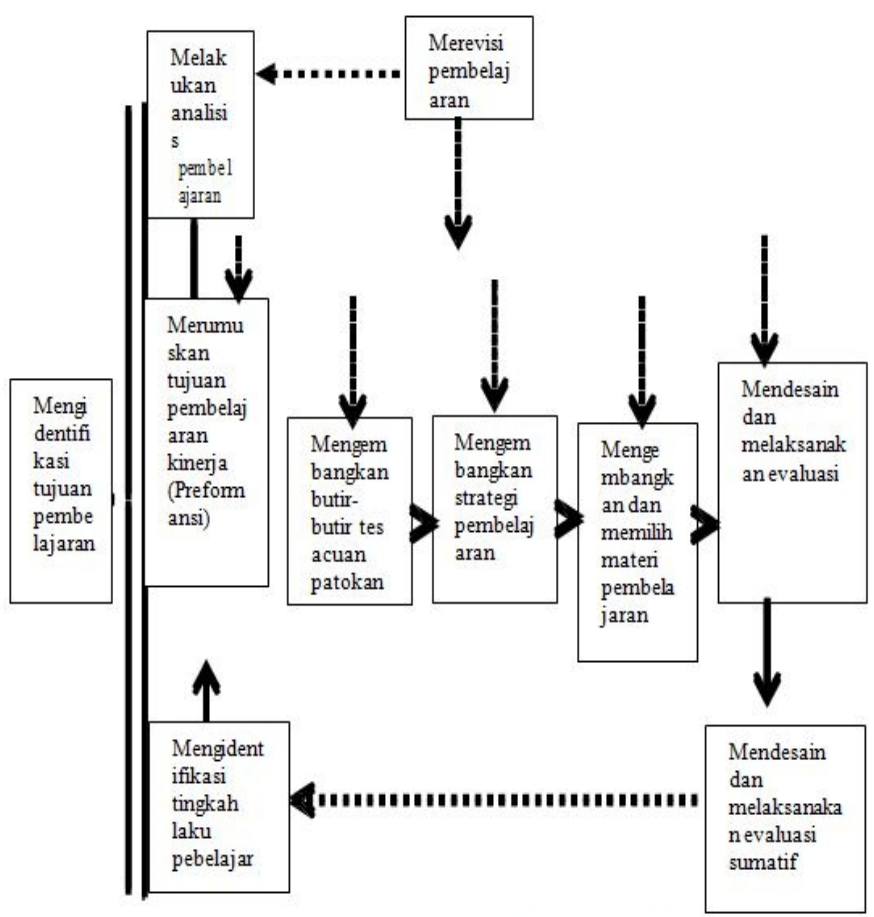

Gambar 3.1 Perencangan dan pengembangan perangkat

Subjek dalam penelitian ini adalah perangkat pembelajaran model guided discovery dengan pokok bahasan Melakukan Analisis Air dan Mineral yang diimplementasikan pada siswa SMKN 1 Cerme Gresik kelas XI. Penelitian dilakukan terhadap siswa kelas XI AK1 dengan jumlah 32 siswa.

Dalam penelitian ini, untuk mendapatkan data penelitian digunakan beberapa teknik pengumpulan data, 
yakni sebagai berikut:

1. Tes

Tes digunakan untuk mengetahui ketuntasan hasil belajar, pemahaman konsep kimia dan ket- erampilan berpikir kritis siswa.Tes ini diberikan saat pretest dan posttes.

\section{Observasi}

Teknik observasi bertujuan untuk mengumpulkan data penelitian dengan menggunakan lembar pengamatan yang telah dikembangkan oleh peneliti.Observasi menggunakan beberapa instrumen penelitian untuk memperoleh data penelitian mengenai aktivitas siswa dan keterlaksanaan RPP oleh guru.

3. Pemberian angket

Teknik pemberian angket dilakukan untuk mengumpulkan data tentang respon siswa terhadap proses pembelajaran. Pemberian angket diberikan pada siswa setelah kegiatan pembelajaran selesai.

Untuk teknis analisis data adalah sebagai berikut:

1. Analisis Validasi Perangkat

Perangkat RPP, BAS, LKS, dan LP yang dikembangkan selanjutnya dilakukan telaah oleh pakar untuk memberikan penilaian. Validitas perangkat pembelajaran di analisis secara deskriptif kualitatif yaitu dengan menghitung hasil penilaian yang diberikan validator berdasarkan skor rata-rata masing-masing komponen. Kreteria validasi perangkat menurutBNSP (2006).

\section{Analisis Keterbacaan Buku Ajar Siswa dan LKS}

Tingkat keterbacaan merupakan gambaran bagaimana tingkat pembacaan siswa terhadap buku ajar siswa dan LKS yang telah dikembangkan.Keterbacaan buku ajar siswa dan LKS dianalisis secara desikriptif kuantitatif berdasarkan persentase dari jumlah kata yang dapat dilengkapi terhadap jumlah keseluruhan kata yang dihilangkan, dengan kreteria menurut sitepu (2010).

3. Analisis Keterlaksanaan Pembelajaran

Keterlaksanaan RPP dianalisis secara deskriptif kualitatif yaitu dengan membandingkan rata-rata skala penilaian yang diberikan pengamat dengan kriteria penilaian menurut Arifin (2012).

4. Analisis Data Pengamatan Aktivitas Siswa Selama Pembelajaran

Aktivitas siswa selama kegiatanbelajar mengajar dihitung persentasenya, kemudian hasil perhitungan dianalisis secara deskriptif kuantitatif Arifin (2012).

5. Analisis Respon Siswa

Untuk mengolah data respona dipergunakan presentase (\%). Data respon siswa dianalisis secara deskriptif kuanti- tatif menurut Arifin (2012).

6. Analisis Hasil Belajar Siswa

a. Ketuntasan Individu
Lembar Penilaian dianalisis deskriptif kualitatif. Secara individu, seorang siswa dapat dikatakan tuntas apabila persentase $(\mathrm{P})$ indikator yang dicapai sebesar $\geq 75 \%$ (kriteria ketuntasan minimal kuriku- lum SMKN I Cerme Gresik).

\section{b. Ketuntasan Indikator}

Satu indikator dikatakan tuntas apabila persentase (P) yang siswa capai tersebut $\geq 75 \%$. Data lembar penilaian, selanjutnya diolah menggunakan gain score (skor peningkatan).

7. Analisis Pemahaman Konsep dan Keterampilan berpikir kritis.

Peningkatan pemahaman konsep kimia siswa dan keterampilan berpikir kritis dalam model pembelajaran guided discovery dihitung berdasarkan skor gain ternormalisasi. Kategori peningkatan yang terjadi sebe- lum dan sesudah pembelajaran dihitung dengan rumus g faktor (N-Gain) yang dikembangkan oleh Hake (1999).

\section{HASIL DAN PEMBAHASAN}

\section{A. Pemahaman Konsep Siswa}

1. Ringkasan Hasil Analisis

Hasil analisis ketuntasan individu menunjukkan nilai rata-rata pemahaman konsep siswa sebesar 83 dengan nilai rata-rata $\mathrm{N}$-Gain sebesar 0,75. Indikator pemahaman konsep yang dipakai pada penelitihan ini adalah mengingat dengan N-Gain sebesar 0,83, memahami dengan N-Gain sebesar 0,73 dan mengaplikasikan dengan N-Gain sebesar 0,75 . Hasil analisis menunjukkan adanya ketuntasan individu untuk seluruh siswa, karena nilainya di atas 75 yaitu di atas KKM menurut kurikulum SMK Negeri 1 Cerme Gresik. Sedangkan hasil analisis nilai N-Gain menunjukkan peningkatan hasil belajar siswa karena nilai N-Gain yang diperoleh di atas 0,7, kategori tinggi menurut Hake (1999).

Tabel 1. Rekapitulasi pemahaman konsep

\begin{tabular}{|c|c|c|c|c|c|c|c|c|}
\hline \multirow{2}{*}{ Siswa } & \multicolumn{2}{|c|}{ Mengingat } & \multicolumn{2}{|c|}{ Memahami } & \multicolumn{2}{c|}{$\begin{array}{c}\text { Mengaplika } \\
\text { sikan }\end{array}$} & $\begin{array}{c}\text { N- } \\
\text { gain }\end{array}$ & Ket \\
\cline { 2 - 8 } & \multirow{2}{*}{ Pretest } & Post test & Pretest & Post test & Pretest & $\begin{array}{c}\text { Post } \\
\text { test }\end{array}$ & & \\
\hline XI-1 & 100 & 0 & 0 & 100 & 25 & 88 & 0,36 & TT \\
\hline XI-2 & 100 & 100 & 29 & 71 & 0 & 88 & 0,75 & T \\
\hline XI-3 & 0 & 100 & 0 & 71 & 38 & 88 & 0,84 & T \\
\hline XI-4 & 0 & 100 & 29 & 71 & 25 & 75 & 0,78 & T \\
\hline XI-5 & 100 & 100 & 29 & 100 & 25 & 75 & 0,84 & T \\
\hline XI-6 & 0 & 100 & 43 & 57 & 16 & 88 & 0,77 & T \\
\hline XI-7 & 100 & 100 & 29 & 71 & 25 & 63 & 0,55 & T \\
\hline
\end{tabular}




\begin{tabular}{|c|c|c|c|c|c|c|c|c|}
\hline \multirow{2}{*}{ Siswa } & \multicolumn{2}{|c|}{ Mengingat } & \multicolumn{2}{|c|}{ Memahami } & \multicolumn{2}{|c|}{$\begin{array}{l}\text { Mengaplika } \\
\text { sikan }\end{array}$} & \multirow{2}{*}{$\begin{array}{l}\mathrm{N}- \\
\text { gain }\end{array}$} & \multirow{2}{*}{$\mathrm{Ke}$} \\
\hline & Pretest & Post test & Pretest & Post test & Pretest & $\begin{array}{l}\text { Post } \\
\text { test }\end{array}$ & & \\
\hline XI-8 & (0 & 100 & 14 & $8 \overline{86}$ & 25 & $\overline{835}$ & 0,89 & 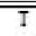 \\
\hline XI-9 & 0 & 100 & 14 & 86 & 25 & 75 & 0.85 & $\mathrm{~T}$ \\
\hline XI-10 & 0 & 0 & 29 & 86 & 25 & 75 & 0,44 & $T T$ \\
\hline XI-11 & 0 & 100 & 43 & 71 & 16 & 100 & 0,87 & $\mathrm{~T}$ \\
\hline $\mathrm{XI}-12$ & 0 & 100 & 43 & 86 & 16 & 75 & 0,83 & $\mathrm{~T}$ \\
\hline $\mathrm{XI}-13$ & 100 & 100 & 0 & 57 & 25 & 75 & 0,50 & $\mathrm{~T}$ \\
\hline XI-14 & 0 & 100 & 42 & 57 & 0 & 62 & 0,58 & $T \pi$ \\
\hline $\mathrm{XI}-15$ & 9 & 100 & 9 & 86 & 38 & 75 & 0,85 & $\mathrm{~T}$ \\
\hline $\mathrm{XI}-16$ & 0 & 0 & 29 & 100 & 25 & 38 & 0,55 & $T T$ \\
\hline XI-17 & 100 & 100 & 29 & 57 & 25 & 75 & 0.53 & $\mathrm{~T}$ \\
\hline $\mathrm{XI}-18$ & 0 & 10 & 29 & 71 & 16 & 38 & 0,83 & $\mathrm{~T}$ \\
\hline XI-19 & 0 & 100 & 0 & 71 & 39 & 72 & 0.41 & $\pi$ \\
\hline $\mathrm{XI}-20$ & 0 & 100 & 43 & 100 & 16 & 88 & 0,95 & $\mathrm{~T}$ \\
\hline $\mathrm{XI}-21$ & 100 & 100 & 29 & 71 & 25 & 75 & 0,63 & $\bar{T}$ \\
\hline $\mathrm{XI}-22$ & 100 & 100 & 29 & 86 & 0 & 72 & 0,77 & $\mathrm{~T}$ \\
\hline $\mathrm{XI}-23$ & 0 & 100 & 0 & 100 & 38 & 75 & 0,91 & $\mathrm{~T}$ \\
\hline $\mathrm{XI}-24$ & 9 & 100 & 14 & 57 & 25 & 85 & 0,79 & $\mathrm{~T}$ \\
\hline $\mathrm{XI}-25$ & 0 & 100 & 29 & 86 & 25 & 75 & 0.84 & $\mathrm{~T}$ \\
\hline $\mathrm{XI}-26$ & 0 & 100 & 29 & 100 & 16 & 88 & 0,28 & $\mathrm{~T}$ \\
\hline $\mathrm{XI}-27$ & 0 & 100 & 0 & 71 & 50 & 100 & 0,87 & $\mathrm{~T}$ \\
\hline $\mathrm{XI}-28$ & 0 & 100 & 29 & 71 & 25 & 88 & 0,83 & $T$ \\
\hline XI-29 & 0 & 100 & 43 & 71 & 25 & 88 & 0,82 & $T$ \\
\hline XI-30 & 0 & 100 & 43 & 86 & 0 & 75 & 0,85 & $\mathrm{~T}$ \\
\hline XI-31 & 0 & 100 & 0 & 71 & 38 & 100 & 0,88 & $\mathrm{~T}$ \\
\hline $\mathrm{XI}-32$ & 0 & 100 & 29 & 100 & 25 & 75 & 0,90 & $\mathrm{~T}$ \\
\hline $\begin{array}{l}\text { Porpo } \\
\text { si } \\
\text { rata- } \\
\text { rata }\end{array}$ & 25 & 87 & 23 & 79 & 23 & 81 & 0 & \\
\hline $\begin{array}{l}\text { Gian } \\
\text { rata- } \\
\text { rata }\end{array}$ & & 62 & & 56 & & & & \\
\hline $\begin{array}{l}\text { Norm } \\
\text { al } \\
\text { gian } \\
\text { rata- } \\
\text { rata }\end{array}$ & & .83 & & .73 & & 75 & Tir & \\
\hline
\end{tabular}

Hasil analisis ketuntasan indikator menunjukkan, seluruh indikator pemahaman konsep telah dikuasai kepada siswa dengan persentase ketuntasan semua indikator diatas 75\% menurut kurikulum SMK Negeri 1 Cerme Gresik. Sedangkan peningkatan hasil belajar menunjukkan 9 indikator pemahaman konsep berada pada kategori tinggi dengan nilai $\mathrm{N}$-Gain lebih besar dari 0.7dan 7 indikator pemahaman konsep berada pada kategori sedang dengan nilai $\mathrm{N}-$ Gain antara $0.7>\mathrm{g}>0.3$.

Aktivitas siswa yang diamati menunjukkan kenaikkan aktivitas dimana aktivitas siswa yang dominan yaitu pada aktivitas pengamatan/percobaan/bekerja, mendengarkan penjelasan dan berdiskusi.Hasil analisis respon siswa terhadap ketertarikan siswa terhadap komponen belajar menunjukan $63 \%$ siswa cukup tertarik terhadap komponen belajar yang dipakai. Sedangkan tingkat kesulitan siswa terhadap komponen belajar sekitar $37 \%$ siswa menyatakan sangat mudah memahami, 58\% siswa menyatakan cukup mudah, 4\% kurang mudah memahami dan $1 \%$ tidak mudah memahami.

\section{Keterkaitan Hasil dengan Pembelajaran}

Perolehan nilai rata-rata pemahaman konsep diatas KKM menunjukkan ketuntasan individu siswa sedangkan peningkatan hasil belajar dengan nilai $\mathrm{N}$-Gain diatas 0,7 merupakan peningkatan hasil belajar siswa mengunakan pembelajaran guided discovery. Pemahaman konsep pada pembelajaran guided discovery ditekankan pada pemberian motivasi siswa diawal pembelajaran. Hal ini bertujuan untuk mengaitkan konsep-konsep yang telah dimiliki siswa sebelumnya dengan masalah yang dihadapi pada kehidupan sehari-hari.

Hasil analisis ketuntasan indikator pemahaman konsep menunjukkan seluruh indikator telah dipelajari siswa dengan menggunakan model pembelajaran guided discovery. Indikator pemahaman konsep disajikan pada tiap fase pembelajaran diawali dari pendahuluan pembelajaranyang meliputi pemberian pertanyaan untuk menguatkan kansep-konsep kimia siswa. Pada kegiatan inti pemahaman konsep lebih banyak dikuasai siswa mulai dari menentukan alat dan bahan, membuat zat kimia yang digunakan dengan melakukan hitungan kimia terlebih dahulu.

Aktivitas siswa dalam melakukan diskusi untuk menentukan langkah-langkah analisis menunjukkan peningkatan aktivitas pada tiap pertemuan. Untuk menghindari kesalahan konsep pada saat melakukan analisis, siswa melakukan aktivitas berpendapat dan berdiskusi sesama teman satu kelompok pada saat melakukan kegiatan penemuan. Aktivitas pengamatan siswa saat melakukan analisis semakin tinggi diikuti aktivitas siswa melakukan kegiatan pencatatan untuk 
mencatat hasil selama proses analisis. Sedangkan respon siswa menunjukkan penjelasan guru selama KBM dan bimbingan guru selama proses penemuan cukup mudah diterima dan dipahami dengan menggunakan pembelajaran guided discovery.

\section{Kaitan Hasil dengan Perangkat Pembelajaran}

Peningkatan aktivitas siswa, ketuntasan individu, ketuntasan indikator dan peningkatan hasil belajar dipengaruhi oleh perangkat yang digunakan guru meliputi RPP, BAS, LKS dan Lembar penilaian. RPP yang dibuat mengacu pada model pembelajaran guided discovery. Di RPP dituliskan tujuan pembelajaran pada ranah pemahaman konsep untuk tiap pertemuan. Di awal pembelajaran, guru memberi motivasi berupa cara mecicipi sayur untuk penerapan konsep pengambilan sampel yang benar.

Pada analisis alkaliniti, guru memberi motivasi tentang kemacetan kran air yang menunjukkan penerapan pemahaman konsep siswa tentang akibat terjadi karat pada kran tersebut. Untuk analisis kesadahan, guru memberi motivasi dengan membawa panci berkerak untuk penerapan konsep pada siswatentang terjadinya kerak pada panci yang digunakan untuk memasak air. Pada pemotivasian analisis klor aktif ditampilkan gambar ikan mati pada suatu perairan. Hal ini untuk membangkitkan keingintahuan siswa tentang adanya zat kimia yang menyebabkan ikan mati. Sedangkan pemotivasian tentangzat padat terlarut, siswa diminta membandingkan kekeruhan air isi ulang dengan air galon.

Pemahaman konsep pada BAS ditunjukan dengan pemberian penekananpada penyajian materi yang penting untuk dipelajari siswa. Bagian yang dipelajari dipisahkan dalam bab tersendiri untuk memudahkan pemahaman konsep siswa. Analisis alkaliniti dibahas pada Bab Titrasi Asam Basa, karena konsep dasar analisis alkaliniti adalah titrasi asam basa. Bab Titrasi Kompleksometri adalah konsep dasar analisis kesadahan yang menyajikan pelarut kompleks yang digunakan untuk analisis kesadahan. Pada analisis klor aktif di bahas dalam Bab Titrasi Oksidasi Reduksi, karena dasar analisis klor adalah reaksi redoks. Sedangkan untuk analisis zat padat terlarut dibahas pada Bab Gravimetri, karena prinsip utama dari analisis tersebut adalah pengendapan dan penimbangan. Aktivitas siswa saat berdiskusi sekitar $16 \%$ dari 8 aktivitas yang diamati. Salah satu kegiatan yang diskusikan siswa adalah materi BAS. Respon siswa sendiriterhadap BAS yang digunakan dalam proses belajar menyatakan sangat tertarik. Hal itu dapat dilihat dari keterbacaan siswa terhadap BAS sekitar 63, yang berarti BAS mudah dimengerti dan dipahami siswa.

Pemahaman konsep siswa dilatihkan dalam LKS yang telah dibuat, yang meliputi LKS 1 persiapan sampel,
LKS 2 merancang percobaan alkaliniti, LKS 3 merancang percobaan kesadahan air, LKS 4 merancang percobaan analisis klor aktif, dan LKS 5 merancang percobaan analisis zat padat terlarut. Pada masing-masing LKS disajikan beberapa pernyataan yang terkait dengan konsep-konsep yang dipakai untuk menyelesaikan fenomena yang diberikan. Aktivitas siswa dalam melakukan pengamatan/percobaan saat melakukan analisis cukup tinggiyaitu 19\%, dikarenakan LKS yang digunakan siswa mudah dipahami dan dimengerti sebab memiliki keterbacaan 69. Siswa menyatakan sangat tertarik terhadap penggunaan LKS sehingga membantu mereka dalam melatihkan pemahaman konsep.

Berdasarkan hasil analisis sensitivitas soal pemahaman konsep menunjukkan kamampuan soal mengukur efek pembelajaranguided discovery dimana hampir seluruh soal berada pada kategori baik $\geq 0,30$ (Gronlund dalam wahyudi, 2012). Kerena memiliki sensitivitas soal yang tinggi maka hasil analisis N-Gain pada tes pemahaman konsep pada materi melakukan analisis air dengan model pembelajaran guided discovery pada kategori tinggi.

Indikator pemahaman konsep yang dianalisis dengan $\mathrm{N}$-Gain meliputi mengingat sebesar 0,83, memahami sebesar 0,73 dan mengaplikasikan sebesar 0,75. Hasil tes pemahaman konsep siswa berada pada kategori tinggi berdasarkan kreteria N-Gain yang ditetapkan oleh Hake (1999). Hal ini berarti bahwa pembelajaran dengan guided discovery telah mampu melatih pemahaman konsep siswa.

\section{Keterkaitan Hasildengan Teori Pembelajaran}

Hasil analisis data menunjukkan bahwa pembelajaranmenghasilkan ketuntasan individudiatas KKM. Bila dihubungkan dengan pembelajaran guided discovery yang dikemukakan oleh Burner (2004), bahwaguided discovery memiliki daya serap lebih lama dimana konsep-konsep yang diterima oleh siswa memiliki daya tahan lebih lama pada otak siswa, memiliki efek transfer yang lebih baik. Artinya, konsep-konsep yang telah dimiliki akan lebih mudah diterapkan pada situasi baru.

Pembelajaran guided discovery dapat melatihkan pemahaman konsep kimia siswa dengan hasil analisis $\mathrm{N}$ Gain rata-rata sebesar 0.75. Hal ini menunjukkan peningkatan hasil belajar setelah pemberian pembelajaran guided discovery. Sesuai dengan pernyataan Dahar (1996), konsep merupakan suatu abstraksi dan konsep memiliki peranan penting dalam pembelajaran, karena konsep merupakan batu-batu pembangun dalam berpikir. Pembelajaran guided discovery dapat melatihkan pembahaman konsep siswa yang telah ada dengan bimbingan guru untuk memperkuat konsep tersebut sebagai dasar mempelajari konsep lainsesuai teori motivasi 
Maslow. Melatih pemahaman konsep pada pembelajaran guided discovery menekankan pada kebutuhan siswa untuk mengkonstruksi pengetahuan yang sudah ada sesuai dengan teori konstruktivis menurut Piaget dan Vygotsky.

\section{Keterkaitan Hasil dengan Penelitian yang Relevan}

Penelitian ini menunjukkan penerapan pembelajaran guided discovery dapat melatih pemahaman konsep siswa. Hal ini sesuai dengan penelitian yang dilakukan Purnomo (2011) yang berpendapat bahwa pembelajaran penemuan terbimbing lebih efektif digunakan dalam pembelajaran. Menurut Al Amin (2012), pengembangan perangkat pembelajaran guided inquiry dapat meningkatkan pemahaman konsep siswa. Pada penelitian ini menunjukkan bahwa pembelajaran guided discovery mampu melatihkan pemahaman konsep siswa dengan peningkatan nilai indikator pemahaman konsep yaitu mengingat, memahami dan mengaplikasikan.

Pemahaman konsep siswa merupakan bagian pengetahuan kognitif, hasil penelitian Joolingen (1999) menyatakan pengetahuan kognitif merupakan alat untuk belajar penemuan sedangkan hasil belajar siswa pada pembelajaran guided discovery menujukan peningkatan hasil belajar sesuai dengan penelitian Alfieri (2011). Pemahaman konsep dapat ditunjukan melalui pengamatan beberapa contoh, menguji suatu kasus dan mampu menjelaskan temuan dengan kata- kata yang tepat menurut penelitian Yang (2012).

\section{B. Hasil Melatih Keterampilan Berpikir Kritis Siswa}

1. Ringkasan Hasil Analisis

Hasil analisis ketuntasan individu menunjukkan nilai rata-rata keterampilan berpikir kritis sebesar 77 dengan nilai rata-rata $\mathrm{N}$-Gain sebesar 0.71 . Indikator berpikir kritis yang dipakai pada penelitian ini adalah menilai kredibilitas dengan N-Gain sebesar 0,72 , menilai inferensi dengan $\mathrm{N}$ Gain sebesar 0,67 dan mengambil keputusan dengan $\mathrm{N}$ Gain sebesar 0,76. Hasil analisis nilai rata-rata menunjukkan ketuntasan individu seluruh siswa karena nilainya di atas 75 yaitu diatas KKM menurut kurikulum SMK. Sedangkan hasil analisis nilai N-Gain menunjukkan peningkatan hasil belajar siswa karena nilai N-Gain yang diperoleh diatas 0.7 kategori tinggi menurut Hake (1999).

Tabel 2. Rekapitulasi keterampilan berpikir kritis

\begin{tabular}{|c|c|c|c|c|c|c|c|c|}
\hline \multirow{2}{*}{ Siswa } & \multicolumn{2}{|c|}{ Mengingat } & \multicolumn{2}{|c|}{ Memahami } & \multicolumn{2}{|c|}{$\begin{array}{c}\text { Nen gaplika } \\
\text { skan }\end{array}$} & \multirow{2}{*}{$\begin{array}{l}\mathrm{N}- \\
\text { gain }\end{array}$} & \multirow{2}{*}{$\mathrm{Kt}$} \\
\hline & $\begin{array}{l}\text { Pre } \\
\text { test }\end{array}$ & $\begin{array}{l}\text { Post } \\
\text { test }\end{array}$ & $\begin{array}{l}\text { Pre } \\
\text { test }\end{array}$ & $\begin{array}{l}\text { Post } \\
\text { test }\end{array}$ & $\begin{array}{l}\text { Pre } \\
\text { test }\end{array}$ & $\begin{array}{l}\text { Post } \\
\text { test }\end{array}$ & & \\
\hline XI-1 & 25 & 31 & 13 & 92 & 17 & 96 & 0,67 & TT \\
\hline XI-2 & 19 & 100 & 17 & 58 & 16 & 75 & 0,73 & $\mathrm{~T}$ \\
\hline XI-3 & 13 & 88 & 21 & 54 & 13 & 92 & 0,74 & $\mathrm{~T}$ \\
\hline
\end{tabular}

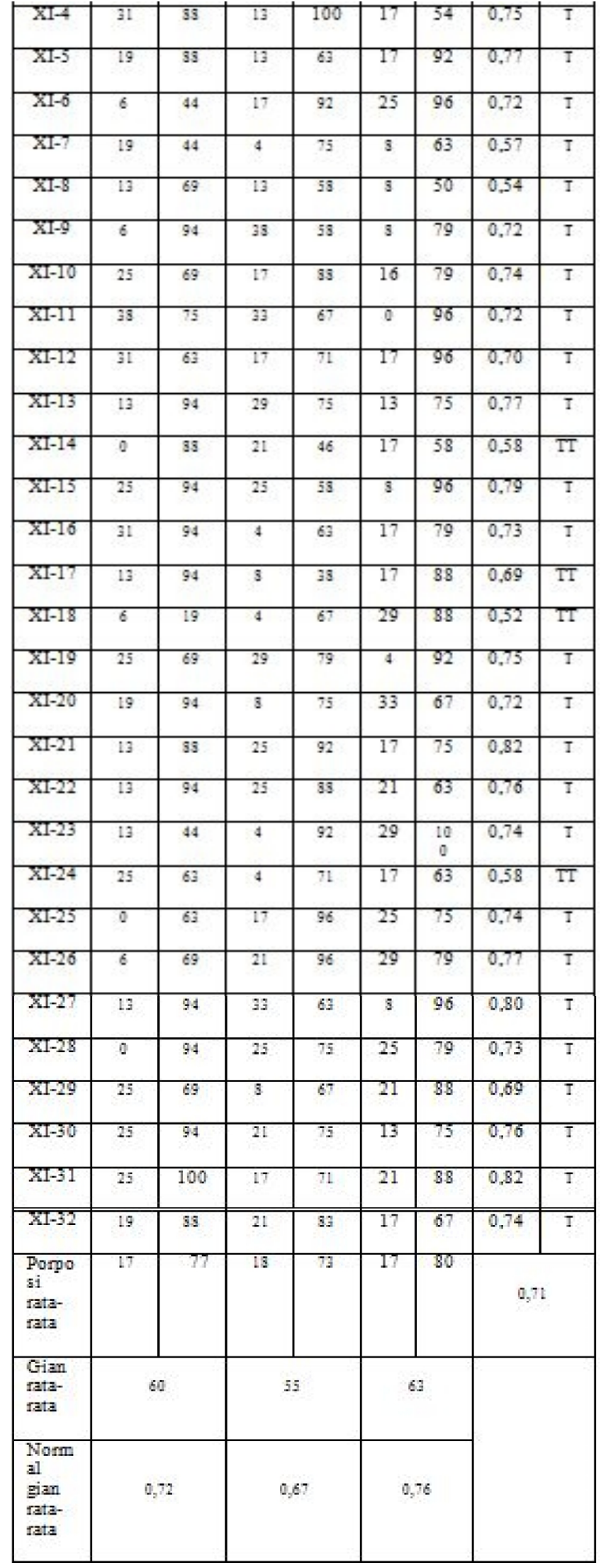

Aktivitas siswa

melakukan pengamatan/percobaan/bekerja dari pertemuan pertama sebesar $17 \%$, pertemuan kedua $19 \%$, petemuan ketiga $19 \%$, sampai pertemuan keempat 19\% mengalami 
kenaikan yang tetap sedangkan pertemuan kelima sebesar 18\% mengalami penurunan dikarenakan LKS 5 lebih lama menunggu kegiatan pengovenan sehingga aktivitas pengamatan/percobaan/bekerja siswa berkurang. Aktivitas pengamatan/percobaan/bekerja banyak dilatihkan keterampilan berpikir kritis pada kegiatan ilmiah untuk menemukan jawaban dari masalah seperti melakukan analisis, membuat argumen, dan melakukan evaluasi yang ada pada LKS siswa. Hasil analisis respon siswa terhadap bimbingan yang dilakukan guru selama melakukan analisis di laboratorium menunjukkan cukup mudah siswa dalammenerima bimbingan guru.

\section{Keterkaitan Hasil dengan Pembelajaran}

Salah satu komponen pembelajaran guided discovery adalah melatihkan siswa dalam penyampaian argumen. Penyampaian argumen dilakukan di awal pertemuan disaat siswa disajikan suatu fenomena untuk melatih keterampilan berpikir kritis siswa. Pada kegiatan penemuan untuk memecahkan masalah melatih siswa menilai kredibilitas dari analisis yang dilakukan seperti merumuskan masalah, membuat hipotesis, menentukan langkah-langkah analisis serta membuat data analisis yang dapat dipercaya. Dari data yang diperoleh siswa melakukan analisis untuk membuat kesimpulan dengan arahan dan bimbingan guru. Dari analisis yang diperoleh dilakukan pertimbangan pendapat dan pertimbangan akibat untuk mengambil suatu keputusan yang bisa dipertanggung jawabkan.

Pembelajaran guided discovery yang dilakukan diperoleh nilai rata-rata keterampilan berpikir kritis diatas KKM yaitu 77 hal ini menunjukkan ketuntasan individu siswa. Sementara itu, peningkatan keterampilan berpikir kritis ditunjukkan dengan nilai N-Gain diatas 0,7 yang menunjukkan peningkatan keterampilan berpikir kritis dalam kategori tinggi.

Keterampilan berpikir kritis pada pembelajaran guided discovery ditekankan pada pelaksanaan penemuan melalui pengamatan/percobaan/bekerja. Hal ini dikarenakan tahapan pengamatan/percobaan/bekerja menuntut siswa melakukan proses berpikir kritis.

Hasil analisis ketuntasan indikator keterampilan berpikir kritis menunjukkan semua indicator tuntas tersampaikan dengan baik kepada siswa dengan menggunakan model pembelajaran guided discovery. Indikator keterampilan berpikir kritis banyak diajarkan pada kegiatan inti pembelajaran guided discovery meliputi merumuskan masalah, menentukan hipotesis, dan membuat kesimpulan.

Aktivitas siswa dalam kegiatan berpendapat meningkat dari tiap pertemuan menujukan kegiatan berpikir kritis siswa juga meningkat. Kegiatan berpendapat siswa seperti penyampaian argumen pada awal pembelajaran atau pada saat kegiatan pengamatan/percobaan/bekerja saat menentukan rumusan masalah, membuat hipotesis dan membuat kesimpulan. Sedangkan respon siswa terhadap bimbingan guru selama proses penemuan sangat mudah dipahami dan membantu siswa dalam menyelesaikan masalah.

\section{Keterkaitan Hasil dengan Perangkat Pembelajaran}

Perangkat pembelajaran yang digunakan guru untuk melatihkan keterampilan berpikir kritis meliputi RPP, BAS, LKS dan Lembar penilaian. Kegiatan pendahuluan pada pembelajaran guided discovery meminta siswa menyampaikan argumen dari fenomena yang disajikan. Pada kegiatan inti melatihkan keterampilan berpikir kritis siswa melalui kegiatan penemuan seperti menilai kredibilitas berupa merumuskan masalah, membuat hipotesis, merencanakan analisis yang akan dilakukan, melakukan pengamatan, menuliskan data analisis. Dari data analisis yang diperoleh dirumuskan kesimpulan sebagai dasar untuk membuat suatu keputusan analisis yang dapat dipertanggung jawabkan kebenaranya. Pada pertemuan terakhir siswa melakukan presentasi untuk melatih keterampilan berpikir kritis siswa.

Keterampilan berpikir kritis pada BAS di tunjukkan dengan pemberian pertanyaan yang membutuhkan keterampilan berpikir tingkat tinggi. Pertanyaan berpikir kritis ada pada tiap bab yang akan dipelajari dimana tiap bab terdiri dari satu sampai dua pertanyaan berpikir kritis. Aktivitas siswa yang menunjukan kegiatan berpikir kritis yaitu berpendapat sekitar $13 \%$ dari 8 aktivitas yang diamati. Respon siswa terhadap keterbaruan BAS dengan menyajikan keterampilan berpikir kritis yang digunakan dalam proses belajar adalah "sangat baru".

Keterampilan berpikir kritis dilatihkan dalam LKS yang telah dibuat, dimana pada masing-masing LKS menyajikan beberapa pertanyaan yang terkait dengan keterampilan berpikir kritis. Di mana keterampilan berpikir kritis dilatihkan sebelum dan sesudah melakukan analisis seperti pemberian pertanyaan sebelum analisis dilakukan berupa memberi argumen, melakukan analisis dan melakukan evaluasi dari pertanyaan yang diberikan serta siswa dilatihkan merumuskan masalah dan merumuskan hipotesis dari analisis yang akan dilakukan. Siswa melakukan analisis data yang diperoleh setelah melakukan kegiatan analisis air dan mineral untuk membuat suatu kesimpulan dan sebagai dasar untuk membuat keputusan dari analisis yang dilakukan. Aktivitas siswa yang melatihkan keterampilan berpikir kritis adalah melakukan pengamatan/percobaan/bekerja, yaitu sebesar 19\%.

Berdasarkan hasil analisis sensitivitas soal keterampilan berpikir kritis menunjukkan kemampuan soal 
yang mengukur efek pembelajaran guided discovery hampir seluruh soal berada pada kategori baik $\geq 0,30$ (Gronlund dalam Wahyudi, 2012). Kerena sensitivitas soal yang tinggi, maka hasil analisis N- Gain pada tes keterampilan berpikir kritis pada materi melakukan analisis air dengan model pembelajaran guided discovery terletak pada kategori tinggi.

Indikator keterampilan berpikir kritis dianalisis dengan N-Gain meliputi menilai kredibilitas sebesar 0,72, membuat inferensi sebesar 0,67, dan mengambil keputusan sebesar 0,76 . Hasil tes keterampilan berpikir kritis rata-rata 0,71 berada pada kategori tinggi berdasarkan kreteria $\mathrm{N}$ Gain yang ditetapkan oleh Hake (1999). Indikator berpikir kritis berada pada kategori tinggi menunjukkan pembelajaran guided discovery telah mampu melatih keterampilan berpikir kritis siswa.

\section{Keterkaitan Hasil dengan Teori Pembelajaran}

Kelas merupakan cerminan masyarakat yang besar dan berfungsi sebagai fondasi demokrasi dan melihat sekolah sebagai laboratorium oleh Dewey dan Thelan (Arends, 2012). Dalam skala kecil laboratorium yang digunakan belajar adalah laboratorium sekolah. Pembelajaran guided discovery merupakan proses penemuan yang dilakukan di laboratorium untuk melatih keterampilan berpikir kritis siswa serta meningkatkan daya nalar siswa.

Pembelajaran guided discovery dapat melatihkan keterampilan berpikir kritis siswa dengan hasil analisis NGain rata-rata sebesar 0,71. Hal ini menunjukkan peningkatan hasil belajar setelah dilakukan pembelajaran guided discovery. Sesuai dengan pernyataan Burner bahwa discovery merupakan belajar penemuan untuk pencarian pengetahuan secara aktif oleh manusia dengan memberikan hasil yang baik.

Pembelajaran guided discovery mencerminkan perilaku kooperatif pada saat melatihkan keterampilan berpikir kritis sebagai dasar demokrasi pada saat analisis di laboratorium untuk mengembangkan perilaku demokratis hal ini sesuai dengan teori cooperative learning menurut Dewey dan Thalen. Pemecahan masalah untuk melatih keterampilan berpikir kritis pada pembelajaran guided discovery menekankan pada kebutuhan siswa menginvestigasi lingkungan dan mengkonstruksi pengetahuan sesuai dengan teori konstruktivis menurut Piaget dan Vygotsky.

\section{Keterkaitan Hasil dengan Penelitian yang Relevan}

Penelitian ini menunjukkan bahwa penerapan pembelajaran guided discovery dapat melatih keterampilan berpikir kritis siswa. Hal ini sesuai dengan penelitian yang dilakukan Akibobola (2012) yang menyatakan bahwa pembelajaran guided discovery dapat membuat siswa melakukan pemecahan masalah, belajar mandiri, berpikir kritis, kreatif, dan bukan menghafal. Sementara itu, Swaak (2004) menyatakan bahwa pembelajaran discovery mengkaitkan kemampuan siswa dalam mengumpulkan informasi, mengklasifikasikan informasi, menyatakan hipotesis serta dapat menyimpulkan informasi yang telah diterima.

Pembalajaran discovery mampu meningkatkan hasil belajar menurut penelitian Balin (2009), sedangkan pembelajaran discovery merupakan dasar kreatifitas siswa dalam proses penemuan seperti penelitian Domainque (1992). Menurut penelitian Cotton (1991) menyatakan informasi dan fakta-fakta yang diperoleh pada pembelajaran guided discovery tidak lepas dari pengembangan keterampilan berpikir kritis.

\section{Singkatan dan Akronim}

MAAM (Melakukan analisis air dan mineral) merupakan salah satu mata pelajaran yang melatih siswa melakukan analisis air meliputi analisis alkaliniti, kesadahan, klor aktif, dan zat padat terlarut guna melatihkan penguasaan konsep dan keterampilan berpikir kritis.

\section{PENUTUP \\ Simpulan}

Berdasarkan keterbacaan BAS dan LKS menunjukkan tingkat keterbacaannya mudah dipahami dan terbaca oleh siswa karena berada pada kategori $>50 \%$. Untuk keterlaksanaan pembelajaran berada pada kategori cukup baik yaitu 3,6, sedangkan aktivitas siswa mengalami peningkatan selama pembelajaran. Ketuntasan individu menunjukan 27 siswa telah tuntas mempelajari pemahaman konsep dan keterampilan berpikir kritis. Ketuntasan indikator untuk soal pemahaman konsep dan keterampilan berpikir kritis menunjukkan semua indikator telah tuntas dipelajari oleh siswa dengan ditunjukkan nilai diatas 75 .

Selanjutnya berdasarkan analisis N-Gain menunjukkan pemahaman konsep tiap individu sebesar 0,75 yang berarti berada pada kategori tinggi. N-Gain pada indikator pemahaman konsep sebesar 0,74 yang berarti pada kategori tinggi. Hasil analisis N-Gain keterampilan berpikir kritis tiap individu sebesar 0,71 termasuk dalam kategori tinggi. N-Gain pada indikator keterampilan berpikir kritis sebesar 0,76 termasuk dalam kategori tinggi. Pada analisa respon siswa terhadap perangkat pembelajaran yang telah digunakan menujukkan respon yang "sangat dan cukup baik".

Berdasarkan kesimpulan hasil penelitian bahwa perangkat pembelajaran yang dikembangkan melalui model 
pembelajaran guided discovery dapat melatih pemahaman konsep dan keterampilan berpikir kritis siswa SMK Negeri 1 Cerme Gresik pada mata pelajaran Melakukan Analisis Air dan Mineral (MAAM) materi pokok Melakukan Analisis.

\section{Saran}

1. Untuk mendukung pemahaman konsep pada kompetensi keahlian kimia analisis sebaiknya lebih diutamakan pada ranah kognitif C3 yaitu mengaplikasikan. Ranah kognitif C3 diperlukan untuk mengaplikasikan konsepkonsep yang mendasari analisis yang akan dilakukan seperti pada saat menentukan pemakaian bahan, alat serta prosedur yang digunakan untuk analisis maka diperlukan konsep-konsep kimia yang mendukung analisis untuk menghindari kesalahan saat analisis dilakukan.

2. Indikator keterampilan berpikir kritis untuk penelitian selanjutnya perlu ditambahkan "menganalisis pertanyaan atau masalah" indikator ini diperlukan untuk mempermudah melakukan tindakan awal dalam melakukan analisis seperti menganalisis masalah yang disajikan sebelum menentukan jenis analisis yang akan dilakukan.

\section{DAFTAR PUSTAKA}

Al Amin, Rouf. 2012. Pengembangan Perangkat Pembelajaran Fisika SMA Model Guided Inquiry Untuk Meningkatkan Pemahaman Konsep Siswa Pada Materi Listrik Dinamis. Tesis Tidak di Publikasikan: UNESA.

Alfieri L, Brooks P.J, Aldrich N.J and Tenenbaum H. R. 2011. Does Discovery Based Instruction Enhance Learning? Journal of Educational Psychology. Vol.103 No.1, pp. 1-18.

Akinbobola, A. O and Afolabi, F. 2009. Constructivist Practices Through Guided Discovery Approach: The Effect On Students Cognitive Achievements In Nigeria Senior Seconder School Phisics. Bulgarian Journal of Science and Education Policy (BJSEP). Vol.3 No.2, pp.233-252.

Arends I Richard. 2012. Learning To Learning. New York, NY 10020: McGraw Hill Companies, Inc.

Arifin, Z. 2012. Evaluasi Pembelajaran Prinsip, Teknik dan Prosedur. Bandung: Remaja Rosdakarya.

Balim, A, G. 2009. The Effects of Discovery Learning on Students Succees and Inquiry Learning Skills. Journal of Educational Research. Vol.35, pp. 1-20.

BSNP. 2006. Standar Isi Untuk Satuan Pendidikan Dasar dan Menengah Standar Kompetensi dan Kompetensi Dasar SMK/MAK. Jakarta: Badan Standar Nasional Pendidikan.
Brunne, J. 2004. An Overview of Jereme Brunner His Theory of Constructivism. In Partial Fullfillment of The Requirements For ECI 761.

Dahar, R.W. 2011. Teori- Teori Belajar \& Pembelajaran. Jakarta: Erlangga.

Dick, Walter and Lou Carey. 1990. The Systematic Design of Instruction. Florida: Harper Collins Publiser.

Domaingue Robert. 1992. Learning For Discovery: Establishing The Foundations. Journal of Scientifie Exploration. Vol.6 No.1, pp. 11-22.

Cotton, Kathleen. 1991. Teaching Thinking Skills. Regional Educational Laboratory:http://www.nwrel.org/scpd/sirs/6/cul1.ht ml. Vol. 11, pp. 1-19.

Grounlund, N. E. 2003. Assessment of Student Achievement. New York: Person Education Inc.

Hake, R.R. 1999. Analyzing Change/gain scores. Woodland Hills CA 91367 USA: Indian University.

Joolingen, W. V. 1999. Cognitive Tools For Discovery Learning. University of Amsterdam: International Journal of Artificial Intelligence in Education. Vol.10, pp. 385-397.

Nur, M. 2012. Pengembangan Bahan Ajar untuk Memberi Kemudahan Guru Mengimplementasikan Inovasi Pembelajaran. Surabaya: PSMS UNESA.

Purnomo, Yoppy Wahyu. 2011. Keefektifan Model Penemuan Terbimbing dan Cooperative Learning Pada Pembelajaran Matematika. Jurnal Kependidikan. Vol.41 No.1, hal. 37-54.

Sitepu, B.P. 2010 keterbacaan (http://bintang sitepu. Wordpress. Com/ 2009/ 09/ 11/ keterbacaan/)

Swaak, Janine Tong de Jong \& Wouter R V Joolingen. 2004. The Effects of Discovery Learning and Expository Instruction on The Acquistition of Definitional and Intuitive Knowledge. University of Amsterdam The Netherlands: Journal of Computer Assisted Learning. Vol.20, pp. 225-234.

Wahyudi. 2012. Developing Chemistry's Learning Media Based on Cooperative Approach of Student Teams Achievement Division Type in Improving Process and Student Learning Outcomes Quality at SMA Negeri Marawola. Magister of Science Education Postgraduate Program Tadulako University.

Yang E. F. Y, Liao C.C.Y, Ching E, Chang T, and Chan T.W. 2010. The Effectiveness of Inductive Discovery Learning in 1: 1 Mathematics Classroom. Journal International Conference on Computers in Education. Vol.18, pp. 